\title{
Governance and Language Loss among Youths in Nigeria
}

\author{
Ofodu Graceful Onovughe (Ph.D) \\ Institute of Education Faculty of Education Ekiti State University, Nigeria
}

\begin{abstract}
The language of a people is the identity, culture and value of such a people and if the government of such people down plays the place of language, there will be chaos and anarchy. This paper looks at governance and language loss among youths in Nigeria. The major method of this investigation was basically literature review. It highlights the various language policies of the government of Nigeria before and after independence. It laments the situation of language use and attitude of youths in many Nigerian communities. It traced the possible causes to such variablesasnon-implementation of government policies concerning language, prohibition of vernaculars in schools, ineffective service delivery, parental choice of English language in many homes, influence of music and the entertainment world where most advertisements are done in pidgin. The resultant effects are loss of moral and social values, manifestations of endangerment of the three major languages and total languageloss of many minority languages in Nigeria. Based on these, it was recommended that the government at all levels as well as individuals must empower Nigerian indigenous languages so as to stem the tide of language loss.
\end{abstract}

Keywords: Culture, Language learning, Acquisition, Language endangerment

\section{Introduction}

Language is a very important natural and unnatural phenomenon in any society. Its importance entails the whole spheres of life of the citizens. Language has codes and systems that are used for representations and communication. Communication is at the center of any language acquisition and learning processes because it is basic to the transmission of values, culture and the identity of a people. A loss of a language translates to the loss of a people, their values, culture and identity.

No scholar has been able to perfectly define the concept of language. But a look at some perspectives of scholars on language will be expounded. Ngugi (1994) sees language as having a dual character: a means of communication and a carrier of culture. Language carries culture and culture carries particularly through orature and literature, the entire body of values by which we come to perceive ourselves and our place in the world. This implies that language and culture are inseparable duo by which people perceive themselves.

Within the context of this paper, language can be defined as anything that enables a person to express ideas, emotions, facts and disseminate pieces of information to people in an understandable manner. It enables people to interact and transact within any society. Language is one of the sterling features of human beings that make human interaction peaceful, possible and pleasant. It is a natural resource that can be used for personal, communal and national development.It is important to explain that language can be acquired or learnt.

One of the characteristics of any language is that it can be acquired or learnt.

Language acquisition is the natural process by which a child acquires a language from the parents, or the immediate environment without being taught. It is not learnt by the child. This is premised on the theory that every human being has a mental ability to acquire a language depending on the exposure from infancy. To Chomsky (1968) language acquisition is an innate affair,as every child has Language AcquisitionDevice which enables the child to acquire the first language depending on the favourable environment. This first language is often called mother tongue, which is the first language a child acquires from his parents. But, it must be pointed out that sometimes the child's mother tongue may not necessarily be his first language. Therefore, mother tongue is the first language acquired by a child in sequence and performance

Language learning on the other hand deals with the conscious process by which a language is learnt. The learnt language, more often than not, is a second language. This involves a deliberate and formal process of learning a second or third language. One theory that supports this is Skinner's Behaviourism.

The mother tongue of a child is the language of his speech community which he acquires early in life and subsequently becomes his instrument of thought and communication. It is the medium of intimate instruction and communication at home. Mother tongues are closely related to the psyche of the people who use them (Ogunsiji 2001). Do they possess any value at all?

The indigenous languages in Nigeria are often called vernaculars, mother tongues, and indigenous languages, major and minor languages in Nigeria. Whatever they are called matters less but the benefits in educating a child with these languages are inexhaustible and therefore deserve to be expounded. This may be the 
reason why countries like Japan, India, Russia, Tanzania have long developed their mother tongues and experience advancement in science, technology, politics, economics to mention a few. Scholars (Fafunwa, Macaulay \& Osokoya 1989, Adeosun 2010, Ogunlola 2012) have highlighted the tremendous benefits of mother tongue on the total development of youths as follows:

Knowledge acquisition is one of the key functions of education.One of the best means of acquiring and disseminating knowledge is the use of mother tongue. This is owing to the fact that if children understand better when the language of their mother tongue(which is frequently used at home) is used for instruction. Better learning takes place in all situations as children communicate easily and eagerly with mothers, neighbours, siblings, grandparents etc. There are many teachers at children's disposal who teach and correct them without any threat of discipline or punishment because the learning environment is friendly and child-centred.

Technological development is today the talk of many countries and a look at some advance countries of the world shows they instruct their children with their mother tongues, having closely examined the benefits. Nnolim (2007) asserts that a young Japanese student revealed that in looking over undergraduates notes taken by his ancestors in Japanese universities in the 1850s, he noted that his grand -father took all his notes in English, his father half in English and half in Japanese and his own notes are completely in Japanese. Little wonder Japan has a strong indigenous technology that is the envy of many world powers.In Nigeria, observation and experience have revealed that many educated men and women often seek the assistance of roadside technicians (who are stark illiterates but who were instructed in their various professions with their mother tongues) for technological appliances, advice and assistance (mechanics, electricians, welders, cobblers). Ifthe government can just give a little impetus to the development of indigenous languages, may be Nigeria could have the desired transformation we long for.

Political stability can be better attained when the affinity between the polity and political leaders are bound by a common tie: the language of the people by the people and for the people. Ogunlola (2012) adds thatlanguage misunderstanding is often the cause of rancor, disaffection, conflicts and civil unrest.

Ogunlola (2012) opines that the best language to use to teach a child Economics, Business and Commerce is the mother tongue and such a child will be versed in the art of trading. He adds that business transaction of any form involves very close interaction and this is made easier via the use of mother tongue.Interaction is one of the functions of language. It is a required skill for language acquisition, learning and development. The use of the mother tongue is paramount in effective social interaction because one communicates best in it. But unfortunately, in Nigeria, children are prohibited from speaking their mother tongues in schools because it is regarded as a vernacular, and they are sometimes made to pay fines for speaking it. Consequently, many children are quiet, learn little or nothing in class and fail at the end because they could not interact with the imposed language of interaction, English. Egbe, Bassey \& Otu (2004) observe that the consequences of the situation painted above are enormous as they affect other aspects of life: achievement in the field of education is lower than it should be, productivity is low and social interactions are inhibited.

Ofodu (2012) observes that we live in a society where moral rectitude is almost extinct and many young ones have gone haywire. One of the possible causes of this moral bankruptcy is the use and dominance of a foreign and cultureless language. Moral values are taught through a people's language and literature such as tales, myths, taboos, songs, proverbs, stories, religion and so on (Ogunlola 2012). Again, the use of mother tongue leads to cultural enrichment, cultural preservation and sustainability

It is rather very unfortunate that as laudable as these benefits are, the government is not doing anything substantial about educating our youths in the indigenous languages. Therefore, many youths are fast losing their languages. What then are the possible causes of language loss among our youths? What are the effects of these causes on the future generation of this great country? Theseconcerns are the main thrust of this discourse.

\section{Language Loss and its Historical Antecedents in Nigeria}

Language loss refers to loss of a language by a people as a result of the superordinate influences of a second or third language. It is the loss of a mother tongue (minor or major language) by an individual or community. Language loss is the result of a systematic or random reduction in the form and content of a language and its spheres of competence. When a language is being lost, it may undergo substantial changes in structure especially in the speech of younger generation (Trask 1996, Rafiu 2012).

The loss of a language translates to the loss of a people's uniqueness, identity, accomplishment and culture. There are various stages of language loss according to Fishman (1991). They are:

Stage 1: Here only a few elder people speak the language. This is a critical stage because children and youths cannot speak the language so the possibility of a generation speaking the language is eliminated. The language is endangered and closest to extinction

Stage 2: At this stage, the language can only be spoken by adults who are above child bearing age. This simply translates to fact that children and youths cannot speak the language so the possibility of the next generation speaking the language is limited. This is also a critical stage of language loss. 
Stage 3: There is intergenerational use of the language by parents

Stage 4: Language is still used in the community

Stage 5: Language is required in elementary school

Stage 6: Language is used in places of business and by employees in less specialized work places

Stage 7: Language is used by local government and in the mass media in the minority community

Stage 8: Some language use by higher levels of government and in higher education

It must be noted that in Fishman's eight stages of language loss, stage one is the closest state to language death while stage eight is the closest to language revival, survival and sustainability. With these stages of language loss, it is obvious that many minority languages in Nigeria will soon be lost.

Nigeria is one of the nations of sub-Sahara Africa. Before the colonial government came to amalgamate the southern and northern protectorates Nigeria, the geographical area called Nigeria today had been in existence. It was made up of people of various ethnic entities with a common identity. They lived in various communities with their communal language, people, culture and leaders (Taiwo,(1986). Supporting this assertion, Osokoya (1997) claims that in the pre-colonial period, the area called Nigeria was made up of various independent ethnic groups commonly called tribes which were a people with a different indigenouslanguages, fairly common tradition and territory. These ethnic groups had their distinct way of educating the young ones via the medium of their indigenous languages. The system of education was aimed at inculcating attitudes and values in children. Children were corrected whenever a wrong sound or speech was made. Character development was one of the main objectives of such education and the responsibility of building a good character was not left to parents alone. Neighbours, relatives, peer groups and members of the community contributed their quota.

Moreover, youths were taught indigenous proverbs, riddles and folktales that dwelt on moral and ethical behaviour, and the consequences of bad behaviour and misconduct. It was an education that attached a high premium on cultural transmission. Children learn by imitation, observation, and participation in activities or actions of elders. In short, it was an educational system that encouraged social responsibility, job orientation, political participation, spiritual and moral values (Osokoya, 1997). It is important to state that all these were possible because the medium of instruction at home and in the communities was via the indigenous or mother tongues.

Historical evidence revealed that the beginning of language loss started before independence with the Portuguese merchants. The Portuguese were the first Europeans to visit the West African Coast. On arrival, they discovered that communication was a serious problem. The Portuguese made various attempts to communicate with the natives, and the mixture of Portuguese variety of English and the various indigenous languages gave rise to what is today known as Pidgin (Igboanusi, 2002a, Igboanusi 2002b).This contact also resulted in a number of linguistic or quasi-linguistic behaviours as enunciated by Awonusi (2004):

*The emergence of the use of English with some levels of imperfections

*The gradual acculturation of Nigerians

*The emergence of bilingualism and language mixing

The second stage of language loss was the coming of the British and English - speaking missionaries in large numbers to the southern part of Nigeria as from 1842-1912 and the question of a language to be adopted for communication between the indigenous population and the missionaries emerged (Igboanusi, 2004). First, the missionaries had to learn the indigenous languages of the people and translated the Bible and prayer books into indigenous languages and second they had to train some in the use of English language in order for them to function as interpreters. This effort of the missionaries at translating the bible and other literacy resources is worth of note as some Nigerian languages would have been completely dead if not for the legacy

In addition, Taiwo (1986) observes that the enactment of the ordinance of 1882 when one of the conditions for grants in primary schools was that the subjects of teaching shall be the reading and writing of the English language aggravated the loss of the indigenous languages. Apart from this ordinance, The Education Ordinances of 1896, 1916 and 1926 also favoured the promotion of English language over indigenous languages. In all these ordinances the teaching of English was compulsory in formal schools. Closely associated to this was the introduction of certification system in education. A pass in English was an essential prerequisite to obtaining a certificate in all examinations, appointment in government service and commercial firms (Oyetade 2001).

Moreover, before and after independence, the attitude of Nigerians towards indigenous languages also encouraged indigenous language loss. For instance, Awoniyi as cited in Oyetade (2001) reported that when vernacular was introduced in adult schools in Eastern Nigeria, students withdrew from classes. Again, after independence, the attitude of Nigerians to indigenous languages calls for great concern. This was clearly manifested in the criticisms that greeted the Ife Six Year Primary Project of 1969; the Nigerian public was very skeptical and is still skeptical as they do not see the potency and advantages inherent in any other Nigerian language as a lingua franca. 


\section{Contemporary Causes, Cases and Effects of Language Loss among Youths in Nigeria}

There are many causes, cases and effects of language loss in Nigeria. Prominent among them are:

Inter-tribal or mixed marriage: Inter-tribal marriage is good and should be greatly encouraged in Nigeria but it must be pointed out that it is a contemporary index of language loss among youths. For instance, if an Urhobo lady marries an Igbo man, she might lose her language after some time to the language of her husband or English language if the husband decides not to speak Igbo language for her convenience. The husband is also forced to lose his language and the off springs of such a union are the worse hit as they may neither speak Igbo nor Urhobo. They may either settle for the language of the immediate environment or English. In Nigeria, this situation is very common, but the most unfortunate side of this is that the parents of such children bask in the euphoria that their children can speak English very well instead of both parents' languages.

Another factor that is responsible for language loss is the social and economic values attached to English. Rafiu (2012) observes that young people are mostly found in this category. In Nigeria for instance, many young men and women who win lotteries to other countries have to learn the language of wider communication in order to have access to economic opportunities. Again, many Nigerians in diaspora give up their mother tongue for English.Mowarin (2007) as cited in Rafiu (2012) observes that many languages are being dropped because the speakers see them as barriers to development. Indeed, many Nigerian languages lack economic value; they are neither a requirement for employments, admission, education nor mobility.

Lack of Intergenerational Transmission:Languages are transmitted from one generation to another. A growing number of parents fail to speak their languages to their children. A scenario where most parents prefer their children and wards to speak English rather than mother tongue is disgusting. This attitude to language use by parents portends great danger to our values, culture and the future generations. The possibility and probability of many children being unable to trace their roots is gradually looming.

Music and Drama: Music and Drama are vital communication tools that catch the fancies of young people. Although there are indigenous musicians and drama groups such as'Yoruba Africa magic', observation and experience have revealed that many youths do not listen to and watch the programmes. They do not access local stations where indigenous programmes and languages are utilized.

Death of Surviving Speakers: The death of surviving speakers often times marks the death and loss of a language. In Nigeria, the death of many languages has been reported such as: Ake (Nasarawa state), Bakpakia (Cross River), Butanci, Shau and Kudu-Camo (Bauchi), Chamba (Taraba state), Sheni (Kaduna state), Holma and Honta (Adamawa state), Sorko languages (Niger, Kwara and Kebbi states) (Rafiu, 2012).

Dominance of Foreign languages and Pidgin: English language is a foreign language in Nigeria. It is the language of our colonial masters that has sojourned in Nigeria for over three centuries (Babajide, 2001). Although some scholars have argued that it is a second language rather than a foreign language, the concern of this writer is not to debate about that. Many Nigerian youths do not know this as they grew to use the language in all aspects of life. This erroneous attitude most be corrected. Another foreign language that has thrived so well in Nigeria is French. There is virtually no private school where it is not studied. The teaching and learning of French goes on through college to university. Unlike the ambivalent attitude of Nigerians to indigenous languages, there is positive attitude to French. Arabic language goes along with Islamic religion that is widely practiced in Northern Nigeria, hence Arabic is widely used there and the attitude of Nigerians toward it is positive too. Similarly, the place of pidgin is fast becoming indispensable. It is employed in several television and radio programmes across the country and the audience of these programmes cuts across ethno linguistic, social and religious boundaries. It is the language of advertisements, undergraduates, news dissemination, propaganda, poetry, public enlightenment and mass mobilization (Egbokhare, 2001). Most communication firms in Nigeria also engage their audience patronage through the use of pidgin.

Information and Communication Technologies (ICTs):We live are in an information age where the most consumers of ICT facilities are youths.They spend lots of time exploring 2go, face books, twitters, and English language seems to be the language of communication and enhancement for them.

Government Policies: Governance is a term that refers to the manner, state and authority of an established institution of a country, state or community that manage the welfare of the people. Government dispenses its functions many times through its programmes and policies.As earlier stated, the growth and development of any language to a large extent is a function of government policies. What then are policies? It is a white paper or statement/provision in national documents (constitution, gazettes or educational policy) on a planned course of action (Adegbite, 2003). It must be noted that such a statement is a binding guide meant to be enforced and operated (Ogunsiji, 2003). Based on this, a language policy is a binding language guide meant to be enforced by the society that formulated it through a political process (Ogunsiji, 2003).

Having briefly explained the above term, it is necessary to expatiate how governance has affected the use and loss of languages in Nigeria. There have been various language policies (ordinances) of government in 
Nigeria before and after independence that favoured language loss. But the focus of this study shall be on postindependence policies.

\section{Educational and Political Policies that Favour Language Lossin Nigeria}

There are two language policies in Nigeria when it comes to the place of language. We have the educational and the political policies. These policies gave the English language exalted place and the three major languages the second place. The reasons for these positions are not difficult to decipher. First, the English language has grown to the prestigious language of justice, law, religion, politics and administration, education, mass media and business. Second, the major languages (Hausa, Igbo and Yoruba) have some historical affiliations with the founding fathers (Sir Tafawa Balewa, Nnambi Azikwe and Chief Obafemi Awolowo) of this nation who contributed to the struggle for independence. In addition, they are major languages because geographically they occupy at least five to ten states each and lastly they have large number of speakers (Akande \& Salami,2010).

The National Policy on Education (1977, revised 1981,1998, 2004) is the educational blueprint of the Federal Government of Nigeria which stipulates the government vivid stand on what languages should be used to educate children and youths. It states in Section 1:10 that:

(a)Government appreciates the importance of language as a means of promoting social interaction and national cohesion; and preserving cultures. Thus every child shall learn the language of the immediate environment. Furthermore, in the interest of national unity it is expedient that every child shall be required to learn one of the three Nigerian languages: Hausa, Igbo and Yoruba.

(b) For smooth interaction with our neighbours, it is desirable for every Nigerian to speak French. Accordingly, French shall be the second official language in Nigeria and it shall be compulsory in primary and junior secondary schools but non-vocational elective at the senior secondary school

On the language for educating pre-primary pupils, it states that government shall ensure that the medium of instruction is principally the mother tongue or the language of the immediate community; and to this end will: (i) provide the orthography of many Nigerian languages, and (ii) produce textbooks in Nigerian languages (Section 2:14e)

At the primary school level, the document (section 4:19) states that

(e) the medium of instruction in the primary school shall be the language of the environment for the first three years. During this period, English shall be taught as a subject.

(f) from the fourth year, English shall progressively be used as a medium of instruction and the language of immediate environment and French shall be taught as subjects.

The language of environment shall be taught as L1 where it has orthography and literature. Where it does not have, it shall be taught with emphasis on oracy as L2.

At the secondary school level, one major Nigerian language is a requirement for enrolment at the junior and senior certificate examinations. follows:

The national language policy contained in section 51, 55, 91, and 97 of the 1979 constitution, states as

The business of the National Assembly shall be conducted in English and in Hausa, Igbo and Yoruba when adequate arrangements have been made therefore.

Article 97 of the constitution says for the State House of Assembly that:

The business of a House of Assembly shall be conducted in English, but the house may in addition to English conduct the business of the House in one or more other languages spoken in the state as the House may by resolution approve

Soyoye (2010) asserts that these constitutional provisions while not declaring English explicitly as the official language of Nigeria, gives it the status of the priority language of governance at both the federal and state level. The provision also made Hausa, Igbo and Yoruba as possible language of governance. The question is why the English language is given this exalted position over the major and minor languages? Couldn't we have settled for a language for our development these over fifty years after independence?

Oyetade (2001) adds that all edicts, laws, governmental policy decision, tax forms and all those things crucial to the life of every Nigerian citizen are first handed down in English, so how would the youths of this great nation appreciate any effort at speaking their mother tongue? No wonder, some years ago, the Osun State Government for rationalization purposes laid off a good number of Yoruba language teachers together with teachers of some related humanity subjects.

Just recently, the new curriculum for senior secondary students made both the major and minor languages optional for students; this translates to the fact that, there are no compulsory language subjects. The joy that greeted this new development among youths and parents was unimaginable. This implies that immediately students are through with their junior secondary school, nobody cares about the indigenous languages. Then what is the fate of language teachers in schools? What will happen to these languages in fifty years' time? 
Commenting on the effect of language loss, Chinua Achebe (1995) in a speech titled: The African Writer and the English language questions: Is it right that a man should abandon his mother tongue for someone else's? It looks like a dreadful betrayal and produces a guilty feeling. Similarly, Isola (1995) avers that the socialization of a child into culture or society involves the use of his indigenous language, which is the life blood of any culture and the use of a foreign language by a child can only be a poor second best. Little wonder the hue and cry that accompanies the poor performance of students at both national and international examinations has been very disturbing and appalling. Kolawole \& Adeyanju (2002) observe that the problem is traceable to the use of English language which students have poor knowledge of and so many teachers resort to the use of mother tongue to teach and explain the English language so that students can understand better. He added that there are overwhelming evidence of appalling English expressions in students' notes, scripts, projects and dissertations of undergraduates and graduate students in higher institutions.

Similarly, Reyhner (1999) submits that students who are not being passed down their languages and cultures are often not successful in assimilating the positive aspects of their culture. Instead, they are caught between two cultures without a thorough cultural foundation in any language; the consequence is that they have not learnt their indigenous language or English very well, they are susceptible to joining gangs to seek the cultural identity and sense of belonging that has been denied them.

Youths are the power house of a virile nation. In describing the appalling state of Nigerian youths, Unoh (1982) as quoted by Omojuwa (2005) states that majority of them are ill-prepared for the demand of academic studies by the time they enter tertiary institution, as they depend on short-cuts to knowledge. Perhaps, this is traceable to the foreign language which they use for knowledge acquisition. They seemed to be disillusioned, disconnected and alienated from the values of the founding fathers.

Akere (2004) asserts that there are many literate Nigerians who command native-like competence (spoken and written) in the English language. But, although they speak their mother tongue cannot produce any lengthy written discourse in it; and for many of them, it is just an impossible task to write an informal letter or address the public in their mother tongue. With this situation, can these Nigerians boast of intergenerational transmission of their languages?

Again, the indiscriminate mixing and switching of codes in verbal communication are clear evidence of language loss among many Nigerian youths. One can hardly hear a Nigerian youth speaking without code mixing and code switching to English language. They are neither here nor there. They are not bilinguals because they are neither competent in English nor in their mother tongues.

\section{The Way Forward}

Power and Prestige: Today, all over the country English language is accorded a powerful and prestigious place. It is used as a symbol of national integration and unity. This is because of the years of development it has enjoyed in the country. There should be a reversal of power and prestige between the English language and the indigenous language, and let us see if our languages will not perform the roles of the English successfully? The Federal Government as stipulated in the National Policy on Education should empower and ensure the implementation of the three major languages and the language of the immediate environment. The ability to speak these languages should give socio-economic benefits. The era oflow employability of language graduates should be totally erased. Failure in the indigenous languages should amount to failure in education. This will lead to attitudinal change.

People:One of the ways of securing the future of Nigeria indigenous languages is by encouraging and increasing the number of speakers. This is what we have done to the English language; we have increased the number of speakers when we made it a language of instruction from upper primary school to university level. The ability to write the languages should earn one admission, job opportunities and mobility. This would change the negative and ambivalent attitudes of Nigerians toward the use of the languages and guarantee their viability.

Property: One of the properties of a viable language is that it has orthographies. To develop the orthographies of Nigerian indigenous languages is a way of preventing language loss. This will ensure the readership levels and continuity after many years. The recommendation of Ajiboye cited in Rafiu (2012) is very relevant here. To him, 'those public office seekers, particularly politicians and union leaders should read their manifestoes in the languages of their people either in addition, or as an alternative, to doing so in European languages'. This will add great relevance to the power and prestige of the indigenous languages.

\section{Conclusion}

Finally, let me conclude by saying that this paper has been able to address the contemporary causes and possible effects of language loss among youths in Nigeria with the aim of finding the way forward. Among the 
possible ways out of the woods are empowering and ensuring the implementation of the three major languages and the language of the immediate environment.

The following recommendations for the promotion of indigenous language revitalization in Nigeria were also made:

-The Federal Government in a reviewed language policy should make the study of indigenous languages compulsory for each Nigerian child to the university level. In fact it should be a requirement for admission in addition to other requirements to any higher institution in Nigeria.

- The local, state and federal government should make a credit pass in indigenous language a mandatory requirement for employees at all levels.

-The local, state and federal government should give scholarships to students who study indigenous languages to study within and outside the country.

-Secondary school students who distinguished themselves in indigenous languages should be celebrated nationally and locally.

- Graduates of indigenous languages should be celebrated nationally, locally and should be given automatic employment.

\section{References}

[1]. Adegbite, W. (2003). Multilingualism and national development. In L. Oyeleye \& M. Olateju (Eds.) Reading in language and literature.153-168 Ile- Ife:Obafemi Awolowo University Press limited.

[2]. Adeosun, H.A. (2010). Barriers to child language performance: the case of Yoruba. In D.D. Kuupole \& I. Bariki (Eds).Applied social dimensions of language use and teaching in West Africa. 282-286 Ghana: The University Press

[3]. Ajiboye, T. (2002). Promoting reading readiness in African languages: a factor for African language harmonization. In K.K. Prah (Eds). Rehabilitating African languages. 125-131 Cape Town: The centre for Advanced studies of African society.

[4]. Akande, A. T. \& Salami, L.O. (2010). Use and attitudes towards Nigerian Pidgin English among Nigerian university students'. In M. Robert McColl (Ed.) Marginal dialects: Scotland, Ireland and beyond.70-89.

[5]. Aberdeen: Forum for Research on the languages of Scotland and Ireland.

[6]. Akere, F. (2004).Nigeria English in sociolinguistic perspectives: users, uses and emerging varieties.In A. B. K. Dadzie \& S. Awonusi (Eds) Nigeria English: Influences and characteristics.256-284Lagos: Concept Publications.

[7]. Awonusi, V. O. (2004).Cycles of linguistics History: the development of English in Nigeria. In A. B. K. Dodzie \& S. Awonusi (Eds) English: Influences and characteristics.46-66Lagos: Concept Publications.

[8]. Babajide, A.O. (2001). Language attitude patterns of Nigerians. In H. Igboanusi (Ed.) Language attitude and language conflict in West Africa. 1-13 Ibadan: Enicronfit publishers

[9]. Chomsky, N.A.(1968). Aspects of the theory of syntax. Cambridge: MIT Press

[10]. Egbe, G.B., Bassey, B.U.\& Otu, R.O (2004). Beyond academic reading: Encouraging popular reading for life-long learning.54-58 Literacy and Reading 8.1 .

[11]. Egbokhare, F. (2001). The Nigerian linguistic ecology and the changing profiles of Nigerian pidgin. In H. Igboanusi (Ed.) Language attitude and language conflict in West Africa 105-124. Ibadan: Enicronfit publishers

[12]. Egbokhare, Francis (2004). Language and politics in Nigeria. In K. Owolabi and Dasylva (Eds) Forms and functions of English and indigenous languages in Nigeria: A festschrift in honour of Ayo Banjo. Ibadan: Group Publishers

[13]. Fafunwa, A. B, Macaulay,J.I. \& Osokoya, J.A.F. (1989). Education in mother tongue: Ife primary education project. Ibadan; University Press limited.

[14]. Federal Republic of Nigeria (2004). National Policy on Education $4^{\text {th }}$ Edition $\quad$ Lagos: Federal Government Press

[15]. Fishman, J. A. (1991). Reversing language shift: Theoretical and empirical foundations of assistance to threatened languages. Clevedon, UK: Multilingual Matters.

[16]. Igboanusi, H. (2002a). Igbo English in the Nigerian novel. Ibadan: Enicrownfit Publishers.

[17]. Igboanusi, H. (2002b). A dictionary of Nigerian English usage.Ibadan: Enicrownfit Publishers.

[18]. Isola, A. (1995). The role of Literature in the intellectual and social development of the African Child. In K. Owolabi (Ed.) Language in Nigeria: Essays in honour of Ayo Bamgbose.311-322Ibadan: Group Publishers.

[19]. Kolawole, C.O.O. \& Adeyanju, D. (2002). An examination of the national policy of language education in Nigeria and its implication for teaching and learning of the English language 523-528. Ibadan Journal of EducationalStudies(IJES) 2.1.

[20]. Mowarin, M. (2007). Language endangerment in Isoko land 233-242. In Ndimele, O. (Ed.) Convergence: English and Nigerian languages

[21]. Ngugi, waT. (1994). Decolonizing the mind: the politics of language in African literature 13. London: James Currey Ltd

[22]. Nnolim, C.E. (2009). The Nigerian national language policy and the future of Nigerian Literature. In W. Adegbite \& B. Olajide (Eds.) English in the Nigerian environment: Emerging patterns and new challenges 1-7. Lagos: Nigeria English Studies Association

[23]. Ofodu, G.O. (2012). Family literacy: An essential component of peaceful co- existence in Nigeria. Literacy and Reading 14.1.

[24]. Ogunlola, L. (2012). Mother tongue as a medium of instruction in schools: A case of Yoruba.In D.D.Kuupole, I. Bariki \& R. Yennah (Eds) Cross- currents in language, literature and translation 114-126. Benin: Universitie bilingue

[25]. Ogunsiji, A. (2001). Utilitarian dimensions of languages in Nigeria. In H. Igboanusi (Ed) Language attitude and language conflict in West Africa 152-164. Ibadan: Enicronfit publishers.

[26]. Ogunsiji,Y. (2001). A sociolinguistic study of the language attitude in market transaction. In H. Igboanusi (Ed) Language attitude and language conflict in West Africa 68-96. Ibadan: Enicronfit publishers Ogunsiji, Y. (2003). A critical assessment of educational and political language

[27]. policy documents in Nigeria. In L. Oyeleye \& M. Olateju (Eds) Reading in language and literature. Nigeria: Obafemi Awolowo University Press limited.

[28]. Oyetade, S.O. (2001). Attitude to foreign languages andindigenous language use in Nigeria. In Herbert Igboanusi (Ed) Language attitude and language conflict in West Africa 14-29. Ibadan: Enicronfit publishers

[29]. Osokoya, I.O. (1997). 6-3-3-4 Education in Nigeria: History, strategies, issues and problems. Ibadan: Laurel Educational Publishers 
[30]. Rafiu, K.A. (2012). Halting the tide of language loss in Niger State, Nigeria. In D.D.Kuupole, I. Bariki \& R. Yennah (Eds) Crosscurrents in language, literature and translation.Benin: Universitie bilingue

[31]. Reyhner, J. (1999). Some basics of indigenous language revitalization. In Jon Reyhner, Gina Catori, Robert, N S. Clair and Evangeline, P.Y. (Eds) Introduction to Revitalizing indigenous languages Flagstaff AZ:

[32]. Northern Arizona University. Retrieved 10/5/2013 http://jan.uccnau.edu/jar/RIL.introhtml.

[33]. Soyoye, F.A. (2010). Language in Nigerian society and education: Globalization perspective. In D.D. Kuupole \& I. Bariki (Eds) Applied social dimensions of language use and teaching in West Africa 28-34 Ghana: The University Press

[34]. Taiwo, C.O. (1986). Development of the mother tongue in Nigerian education Lagos: A\& A Publishers

[35]. Trask, R.L. (1996). Historical linguistics New York: Arnold 